\title{
The Transcultural Self: Mapping a French Identity in Contemporary Australian Women's Travel Memoirs
}

\author{
Juliana de Nooy, University of Queensland
}

While a number of Australians recorded their extraordinary experiences in France during the two world wars in diaries and memoirs, ${ }^{1}$ relatively few accounts of Australians in France are available from the second half of the twentieth century, despite greatly increased travel opportunities during this period. This lack has been more than remedied, however, in the first decade of the twenty-first century: whereas only one book-length memoir was published in the 1990s recounting the sojourn of an Australian in France (Kershaw 1993), an astounding thirty-two have appeared since 2000. This is clearly part of a wider Anglophone publishing phenomenon, following the success of Peter Mayle’s A Year in Provence (1990). Unlike their British and US counterparts, however, the recent Australian memoirs are overwhelmingly written by women (26 of the 32), who base themselves as often as not in urban rather than in rural France (Genoni 2007). ${ }^{2}$ They are also clearly marketed to women.

Although they are found in the 'travel literature' section of bookshops, they might more properly be termed 'relocation memoirs,' for in most cases the travel is incidental to the narrative, which focuses instead on the new life created in France, however short the

\footnotetext{
${ }^{1}$ Many are held by the Australian War Memorial. Rosemary Lancaster (2008) examines nurses' diaries 1916-1919 and Nancy Wake's resistance memoir in her study of accounts of Australian women in France 1880-1945.

${ }^{2}$ Paul Genoni in his study of 'village books' (1997)—memoirs of Australians living in Southern Europe- offers hypotheses for the predominance of women authors in this subgenre: Australian publishers anticipating a largely female readership for narratives of resolution of crisis or of romance in exotic locations (223); a gradual feminization of both travel and travel writing (224). Why this gender discrepancy should occur among Australian but not US or British authors, however, remains, an enigma.
}

PORTAL Journal of Multidisciplinary International Studies, vol. 9, no. 2, July 2012.

Imagined Transcultural Histories and Geographies Special Issue, guest edited by Bronwyn Winter.

ISSN: 1449-2490; http://epress.lib.uts.edu.au/ojs/index.php/portal

PORTAL is published under the auspices of UTSePress, Sydney, Australia. 
stay, and accounts of sight-seeing are rare. ${ }^{3}$ The relocation inevitably provides the opportunity for the reinvention of the self in relation to the new surroundings, ${ }^{4}$ and striking are the ease and rapidity with which some of these writers claim a French identity —at least a partial one. ${ }^{5}$ The possibility of acquiring Frenchness is proclaimed in titles such as How to be French (Ambrose 2005), Almost French (Turnbull 2002), My French Life (Archer 2006). How do these women map their identity onto France and what does this Frenchness entail? How do they claim Frenchness when they do not necessarily speak the language or even live in France on a permanent basis? In this paper I focus on four books where the writers give detailed insights into the construction of the French identity to which they aspire, despite undergoing no prolonged cultural or linguistic immersion, and I shall suggest that mapping is a particularly appropriate metaphor for the processes of cultural identification they undergo. ${ }^{6}$

Analysing these processes sheds light on a discourse of identity circulating among a significant subset of Australian women and shows that underpinning the willingness to consume elements of French culture is the desire to reshape one's life in a certain way. And although the books analysed are among the more naive versions of this discourse, its traces are sometimes found even among those of us who have swapped Fouquet's for Foucault, boutiques for Bourdieu.

\section{Vicki Archer: My French Life}

Surprisingly, given the cover photo of a woman approaching the entrance to a Paris metro station, Vicki Archer's My French Life (2006) tells the story of buying and

\footnotetext{
${ }^{3}$ Patrick Holland and Graham Huggan note that Peter Mayle's bestsellers, beginning with A Year in Provance (1990), and which sparked the popularity of the contemporary Anglophone-in-France memoir, 'are travelogues that work to erase their "travel” status, both by establishing a foreign base that assumes the properties of home and by reversing the conventional traveler's distinction between the temporary guest and the permanent host' (1998: 41).

${ }^{4}$ Here I am following Gillian Whitlock in focusing on the autobiographical aspect of the travel memoir: 'To read travel writing in terms of autobiographics is to sharpen the focus on the production of the self in these texts, to think about how the writer might invent herself in relation to place' (2000: 77).

${ }^{5}$ Many of the authors toy with the fantasy of being French, although a number of them end by rejecting this possibility and reaffirming an Australian identity. Interestingly, the longer they stay in France, the better their French language skills, and the more contact they have with Francophones in their day-to-day life, the less likely they are to claim they have acquired a French identity.

${ }^{6}$ Despite the obvious relevance of their titles, space does not allow me to focus at length on Sarah Turnbull's Almost French (2002) or Margaret Ambrose's How to be French (2005). Ambrose's memoir certainly evokes the same familiar myths of France as the others studied in this paper. Her superficial approach to identity distinguishes itself by its competitiveness: 'being French' means being more French (more glamorous, more Francophile) than other Australians, and in particular others in her French class. In contrast, Turnbull's memoir can be seen to engage in a sophisticated genre game with the reader, luring her from the promise of Frenchness to intercultural lessons (Hanna \& De Nooy 2006).
} 
renovating a rural property-Mas de Bérard-in Provence, renovating the 17th century farmhouse, reviving its orchards, and planting 2000 olive trees. Archer presents her story as a romance, but in this case, the love affair is with the farmhouse: 'Falling in love with this place all those years ago changed my life as I knew it; my coup de foudre opened the door to another life, my French life' (2006: 216, and back cover). Although Archer focuses on acquiring a French life, this is seen as a step towards being French, at least to some extent: 'What is it that is so alluring about France? Why do so many people attempt to grasp the life and, in their way become just a little bit French?' (208).

Archer's French life- - both the book and the life it purports to represent—is a work of art. This is partly due to genre constraints: My French Life is a sumptuous coffee-table book, presenting the full mythic view of France as the leader in style, food, and pleasure. $^{7}$ After the preliminary chapters recounting her purchase, the renovation, and the difficulties of acculturation (including linguistic hurdles), the life she has created for herself in France is presented as nostalgic perfection. From the stones to the soft furnishings, from the marketplace to the table setting, from the boutique to the bathroom, the various aspects of place and pastime are lovingly described and exquisitely photographed. Home, book and life are all aesthetic masterpieces. ${ }^{8}$

Emphasis is placed on the work required to achieve that art: the 'hours spent experimenting ... to find exactly the right shade and texture for the interior walls' (48); 'my obsession with perfectly mown avenues of grass between the rows of olives' (178). The ongoing care taken in creating the perfect home-'Mas de Bérard will probably never be finished. I like to think of it as more of a work in progress' (56) - mirrors care of the body: 'French women know that the time spent in the preparation of beauty is not to be undervalued' (37). The carefully tended house and its surrounds are integral to Archer's French life and as such are an extension of her French self. The disciplined olive grove, the disciplined body, the constant attention required to conform to the idealized French life, can be understood in terms of what Michel Foucault termed 'technologies of the self,' 'which permit individuals to effect by their own means or with the help of others a certain number of operations on their own bodies and souls,

\footnotetext{
${ }^{7}$ It is worth noting, however, that Archer's photographer, Carla Coulson, in her own coffee-table memoir of life in France, Paris Tango (2008), mentions cramped living conditions, evictions, public urination, and the stench of the metro, thus resisting the imperative to aestheticize all.

${ }^{8}$ Archer's 2009 sequel French Essence was on sale in the National Gallery of Australia in conjunction with 'Masterpieces from France,' a prestigious exhibition of post-impressionist paintings.
} 
thoughts, conduct, and way of being, so as to transform themselves in order to attain a certain state of happiness, purity, wisdom, perfection, or immortality (Foucault 1988: 18). This undertaking 'implies certain modes of training and modification of individuals, not only in the obvious sense of acquiring certain skills but also in the sense of acquiring certain attitudes' (18).

Foucault considers confession and self-monitoring as important technologies of the self, and Archer's book constitutes a French self both through the confessional practice of autobiography and through the self-observation entailed in framing one's life to be photographed and read. Furthermore, through the didactic mission of the lifestyle book, My French Life participates in turn in an ongoing project of training other disciplined selves.

My French Life proposes a model existence, raising everyday life to an art form: this is a template to follow, and the tools are provided to do so. In addition to the photos of interiors there is a chapter on les femmes, coaching a feminine French self (for the life to be achieved is a distinctly feminine one), giving tips on putting outfits together and emulating French style (68-73). Then there are two appendices: 'my french address book' (220-224) consisting of five pages of restaurants and boutiques, and 'my french inspiration' (225-228), a list of films, music, books to shape one’s mind. Together these provide instruction in fashioning both a French life and a French self of one's own ... with the exception of how to procure the funds to buy and renovate the property, and to engage a manager and a cook to maintain it year-round. The implied reader is thus positioned as aspiring, if not belonging, to a similar social class.

It is important to note that Archer need spend only part of the year in France to achieve her French life. When the family buys the property, she decides that moving from Sydney to Provence would cause too much disruption to her husband's work and her children's schooling. They choose to move to London instead, where the cultural norms of business and education more closely resemble Australian ones. This allows her to 'commute' to Provence to oversee the restoration (11). Archer's French life is thus not the full cultural immersion experience. When she writes that the decision to buy 'opened the door to another life, my French life,' we can interpret 'another' in the sense of an additional life. The move to London enables her to maintain an Anglo life simultaneously. In fact, Archer's French life is only one of three: 'When I am asked the 
question, 'Where do you live?' I can only respond that there is no single answer. The truth is that I feel I have three lives. I live a split life between where I was born and raised, where is feasible for my family and where my heart truly lies' (3). Rather than being torn between cultures, Archer acquires lives. Her French life is a designer accessory to her Anglo existence. Indeed, it is possible that its part-time nature allows Archer to live it in a purer form, uncontaminated by the usual stresses. The farmhouse is the setting for summer holidays that provide 'rare moments with our children, away from the distraction of the city and the pressures of school and university life' (173). Her French life is thus time out from her London life, and there is no compulsion to reconcile the two.

A weekend in Paris suffices as a pretext for a chapter on the capital (99-129) devoted to visits to choice addresses in Paris. Here too, perfection reigns, commodified in exclusive cafés and boutiques. In Archer's French life, even the metro smells delicious thanks to a nearby boulangerie (101). But this Parisian existence is not a fourth life to add to the other three. Slow-paced days in Provence are seamlessly combined with bustling weekends in Paris in a single French life combining rural and urban delights.

From a position of middle-class privilege, ${ }^{9}$ Archer conjures a mythic French life-in the form of an artistic pursuit to which one devotes the time that one can. I now turn to three Paris memoirs that each reproduce elements of this version of Frenchness, but simultaneously highlight aspects of the path towards a French self that are glossed over in Archer's account: the possibility of failure; the role of consumption and performance; and the notion of self-invention.

\section{Janelle McCulloch: La Vie Parisienne: Looking for Love-and the Perfect}

\section{Lingerie}

Janelle McCulloch's La Vie Parisienne: Looking for Love-and the Perfect Lingerie (2008) records a six-month sojourn in Paris and her hopes to return. Like Archer, she lures the reader with the promise of a love story on the cover, and again, the romance is with a place rather than a person—-this time Paris (2008: 27). Paris functions metonymically: the desire for Paris is in fact a desire for a particular art of living. And

\footnotetext{
${ }^{9}$ Archer's position can be compared to a feminine version of the 'monarch of all I survey' with its masculine gaze, sense of entitlement, and eroticized relationship with the exotic destination, identified in travel literature by Pratt (1992).
} 
like Archer, McCulloch presents an airbrushed version of her life in perfect Paris.

When I've finished gazing at perfect pastries I'll wander through lively streetscapes to the rue de Buci street market near St-German-des Prés, an atmosphere-laden neighbourhood on the Left Bank that fulfils just about every fantasy you ever had about being in Paris. (10)

This is my life in Paris, my Parisian life-or la vie Parisienne, as the locals say. And it's what I'd always imagined it to be. An education in style, glamour, gastronomy and grace in a place where even the asparagus spears are exquisite. (11)

However, unlike Archer where the mythical image is maintained throughout her account, McCulloch shifts between two voices in her narration. The panegyric to Paris is undercut by a mocking voice that measures the shortcomings of her apartment, her wardrobe, her love life, her digestive system, her self: 'I could feel my fantasies of an Amélie-style romance among the cobblestones of the Left Bank rapidly receding behind the reassuringly high pile of white French toilet paper' (51). This humorous, selfdeprecating voice exposes her self-doubt and measures the gap between expectation and experience: 'I can't help but adore this place. It is everything that I'm not, but hope to be' (11). The two voices are aligned with different cultural selves: one mockingly described as ‘faux French’ (50); the other Australian. McCulloch constantly oscillates between them, maintaining an ironic distance between the two positions. McCulloch's aspiration is to 'be French' (189) or at least to 'become just a tiny bit more Parisian' (57), but the irony exposes this French identity as 'performative' to use Judith Butler's term: it is 'a normative ideal rather than a descriptive feature of experience' (Butler 1990: 16-17). McCulloch knows she is spinning a fantasy but wants to believe in it all the same: 'You see, the truth is, we all secretly want the fantasy. We want the martini fuelled magic; the richness of a foreign romance. Even if it's only with the city we love' (27).

The construction of McCulloch's new life, her vie parisienne, is painstaking and starts with 'pencil[ing] out a strategy' that will enable her to 'establish ... a life in Paris. A part-time life at first, but hopefully a full-time one before I turn ... too old to enjoy high heels' (37). Then, 'through increasingly extended periods in Paris, I mapped out a new life: one that was as different to my Australian one as stilettos are to thongs' (38). Once again, the new life is feminized and is a product of careful planning and training. McCulloch outlines a variety of technologies of the self to achieve it. And again daily life is elevated to an art form: 'I'd pause here [Ladurée] on an almost weekly basis ... I 
love to come to this irresistible patisserie when I want to be reminded of how beautiful Paris can be—and how even a simple macaroon can become art' (10). ${ }^{10}$

Being Parisian is achieved firstly through leisurely daily routines (38) in picturesque places: writing, walking, lingering in cafés—a far cry from the métro, boulot, dodo [metro, work, sleep] by which many Parisians describe their existence: 'I love to linger in Parisian bistros, bars and cafés, soaking up the atmosphere and the chat. It makes you feel as though you really are a part, albeit a small one, of Parisian society' (148). These routines are part of establishing a connection with place: McCulloch is determined to go beyond the Lonely Planet guide (54) and 'find The Real Paris ... I will find the Paris that only truly dedicated devotees of the city bother to look for, and in doing so, I surmise — or at least I hope with all my heart—-that I shall become just a tiny bit more Parisian' (56-57). And it is the first-hand connection with place that will lend authority to the narrative and confer the cultural identity she desires. ${ }^{11}$

The second requirement of la vie parisienne is glamour and style: 'I've come to Paris to be glamorous. Or at least to be educated in the art of glamour. And now my wardrobe is telling me, in no uncertain terms, that ce n'est pas possible' (93). This will take more work, but McCulloch decides to adopt strategies she identifies among French women (dieting, coffee, hundreds of stairs) before finally determining that the best strategy for glamour is a combination of bluff and self-respect (113).

But disciplining the self goes beyond appearance to learning how to be in a new way. McCulloch starts by making a list of 'Things To Do In Paris,' which will help her with ‘The Getting Of (Parisian) Wisdom’ (56):

\begin{abstract}
Most people come to Paris to climb the Eiffel Tower, wander around the Left Bank, fall in love, find themselves, lose themselves, or just be someone other than themselves for a little while. I come to Paris to do all this but also to try to be a better person-a wiser, kinder, more sensitive, less stressed, and generally more peaceful person. With a lot more style. Like Audrey Hepburn. Only without the gorgeous face and body, obviously. (56)
\end{abstract}

\footnotetext{
${ }^{10}$ For these writers, who wish to distinguish themselves clearly from the experience of mass tourism represented by the Eiffel Tower, the patisserie Ladurée is one of the 'sacred sites' (Rojek \& Urry 1997: 12 ) to be visited. It appears regularly in the various Paris memoirs, making the 'distinction' — a social positioning through judgements of taste (Bourdieu 1979)_available to their audience. Sallie Tisdale (1995: 68) notes that contemporary travel books serve to flatter middle class readers 'who wish to separate from the rabble’ of vulgar tourists (see also Holland \& Huggan 1998: 203-4).

${ }^{11}$ See Stephen Greenblatt (1991: 129) on the rhetorical power of the eyewitness account in conferring authority.
} 
Acquiring a Parisian identity is subsumed into a more general program of selfimprovement: 'to try to be a better person. ${ }^{12}$ Cultural specificity is, however, not ignored entirely. Googling, she 'stumble[s] over a website with odd instructions on être-how to “be” when you live in France' (134). The site highlights the art of telling people off (engueuler, 133-34), and McCulloch adds this to the list of 'social codes' (133) that she is struggling to learn in Paris, which include not smiling at strangers (111), and not replying in the affirmative (133).

In her chapter on 'L’Art de Vivre,' McCulloch comments that 'Lifestyle design is a huge trend at the moment. Huge. We are being designed to within an inch of our lives' (152). Although she is referring to interior design, the remark casts light on her own approach to shaping her new life_-yet she distances herself from it: 'Part of me feels compelled to understand this aspect of Parisian living ... and part of me is alarmed at how seriously they take it all ... These people are so gravely determined to create stylish lives’ (157). Although creating a stylish life is explicitly McCulloch’s project, the 'part of [her]' expressed through the ironic voice finds the self-discipline difficult to maintain and doubts emerge: '[W]hen you work so hard to be someone else, do you eventually forget who you really are? ... The trouble with being in another city and wanting to reinvent yourself is that sometimes the old you still shows through, muddying the grand plan' (112). The old self shows through in that second, more Australian voice. And although at first she claims that her heart belongs in Paris'I may still be an outsider in France but my heart will always belong to Paris' (38)—by the middle of the book she realizes that her heart is difficult to shift: 'I fear that I am, and will always be at heart, an Australian girl from the country' (112) and certainly she continues to use the first person 'we' to refer to Australians (134), never Parisians.

Paris is not perfect after all: she laments the difficulty of belonging, her social isolation in Paris (220-24), her empty love life (227). Ultimately she sees that Paris has wrought positive changes in herself_-however her French self is not characterized by glamour or

\footnotetext{
${ }^{12}$ Richard White notes the legacy of the Grand Tour in the Australian experience of Europe: 'it is intended to be educational, civilizing. The idea is to return a better person, not just a browner one' (1987: 65). Similarly, Ros Pesman (1996: 23-40) examines the purpose of self-improvement among previous generations of élite young Australian women travelling to Europe, often to attend finishing school in order to secure a more favourable marriage. While there are parallels with the quests of the current crop of middle-class travellers - the status conferred by the sojourn in Europe and the veneer of European style-it is important to note that the ability to converse in a foreign language played a much more significant role in the cultural refinement sought by earlier generations.
} 
romance or a French social circle as she originally hoped, but by self-improvement of a more general kind: acceptance of her shortcomings and a more leisurely life of small daily pleasures (233).

\section{Ellie Nielsen: Buying a Piece of Paris: Finding a Key to the City of Love}

In her Buying a Piece of Paris: Finding a Key to the City of Love, Ellie Nielsen, too, suffers from an ‘unrequited love affair with Paris’ (2007: 25). She seeks to 'get a Parisian life' (51), depicted as daily interactions in French with French people about French routines, emblematized by an imagined conversation with the local butcher which bookends the memoir: 'Whilst thanking Monsieur I would purse my lips, shrug a shoulder, and outline my weekend cooking-plans in flawless French' (1; see also 244). Her dream is of 'private Paris,' an invitation-only version of the city not available to tourists: 'Any visitor could delight in public Paris. What I coveted was the élan, the exactitude, of private Paris' (82) like that of her friend's aunt, whose Paris 'was the inner sanctum—not the Paris you could be privy to by chance’ (82).

The goal of a Parisian life is thus understood in terms of belonging rather than of style or glamour and Nielsen is refreshingly candid about her primary technique for attaining it, already acknowledged in her title: 'Buying your way in. That's what I'm trying to do, Jules. It's not honourable' (47). Purchasing a Paris apartment will, she hopes, provide the passport to her integration: 'Despite all my efforts, I've never befriended a Parisian by chance alone. All my intimates here are the friends or family of friends of foreigners like myself. I'm hoping that buying an apartment will change that' (82). When she opens a bank account, she emphasizes the way in which purchase power will distinguish her from the tourist and enable her to buy belonging:

\footnotetext{
[A] Paris chequebook is a licence to buy anything. It will give me a million marvellous opportunities to demonstrate publicly that I am part of this city. I haven't just galloped in to gaze up at the Tour Eiffel or queue up for Sainte Chapelle or sigh into the Seine. I'm going to be where the real Parisians are-inside. My chequebook and I are going to be making all those small, crucial, everyday decisions that make up real Parisian life. That perfect lamp. Those wine glasses. A snowy pair of white cotton pillow cases. (171, italics added)
}

In one of the shortest narrative timeframes of these memoirs, Nielsen gives herself two weeks in Paris (with husband and small son) to buy an apartment, and with it 
belonging. ${ }^{13}$ But this is not her first visit to Paris, and she is sufficiently acquainted with French conventions to be able to make perceptive comments about cultural difference. Early on, she is aware that, rather than buying bringing belonging, belonging may be a prerequisite to buying:

'Don't worry so much,' says Jack, 'You're trying to buy an apartment. It doesn't matter how much of the language you speak; they're still going to be keen to sell you one.'

'Hmmm.' That sounds okay in theory, but in practice I'm not convinced. I've visited Paris enough times to know that my right to purchase a Camembert will be jeopardised if I seem unable to consume it properly. (22)

In contrast to Archer's unacknowledged sense of entitlement, Nielsen recognizes the pitfalls in her plan: a Parisian identity is not so easily commodified and belonging is not simply for sale. And in fact her financial shortcut to belonging is overshadowed by meticulous work on disciplining the self. Her purchase is accompanied by critical selfmonitoring of her language progress and by projecting herself into the role of a Parisian, using techniques informed by her former career as an actress. Already the plan to buy the apartment stems from her 'habit of imagining [her]self in all manner of situations that are outside [her] real, everyday life' (2). Nielsen focuses on the performative aspect of the French identity to which she aspires: 'the "be yourself” idea has never really worked for me. I generally pretend to be some other, better person' (12). Again we see that acquiring Frenchness fits under a general goal of self-improvement.

Nielsen's fortnight in Paris involves a good deal of role play, in an individual-scale theatrical production on the magnificent stage of Paris. To be French, costumes $(3,4)$ and props (87) require attention, but the primary technique is to imagine oneself in the role, as a competent Parisian. As in the theatre, some imaginative work is required: 'Strange, though, how they look pretty much the same as people walking down a busy street in Melbourne. But I ignore that. I always ignore anything that is contrary to my imagined Paris' (7). Unlike Archer, Nielsen exposes the constructedness of ideal Paris as a set(ting), and even points to areas where imagination is insufficient: a café where the table is 'made from cheap, brown wood. Most of the dark-metal window frames are held together by gaffer tape. I shift my gaze to the partially clean brown plastic ashtray, and realise that some things here are not quite as I imagined them. Some things you can't ignore' (145). Similarly, on her way to a theatre in a far from picturesque suburb:

\footnotetext{
${ }^{13}$ And it is also made clear that any future Parisian life in the apartment she buys will involve coming and going rather than full-time residence (200).
} 
'I hurry along the streets, anxious to reach the theatre. It's a bit too real out here' (80). Conscious of the effort of imagination required to preserve her dream and create belonging, Nielsen worries that her performance is insufficiently competent, that she will be 'outed' as a foreigner: 'Why are the beggars of Paris so bloody observant? ... I blush and hurry past in case some other Parisian discovers me for the imposter I so clearly am’ (7-8).

In a departure from the preoccupations of the other three books, Nielsen sees language as a crucial aspect of her performance and a means of belonging in Paris. ${ }^{14}$ The adoption of various language learning strategies finally results in fluency in the final pages'I surprise myself with a rush of sentences' (210)—a fluency that gives her the confidence to buy the apartment and get a Parisian life: 'I don’t feel incompetent, inadequate or excluded. I feel vital: a microscopic part of Paris' swirling, luminous life' (217). However, in a nice irony, her Australianness is confirmed on the very last page, when she feels most Parisian. Her expat friend says that what she loves best about Nielsen is 'Your optimism. It’s so Australian' (244). Like Archer and McCulloch, Nielsen yearns for a French life without committing to live in France, and schools herself to realize it. Unlike Archer, however, and to a greater extent than McCulloch, she foregrounds her awareness of the pretence involved and of the privileged financial situation that enables her quest.

\section{Lucinda Holdforth: True Pleasures: A Memoir of Women in Paris}

Lucinda Holdforth's True Pleasures: A Memoir of Women in Paris (2004) is also the story of producing a new life for oneself. While she never claims explicitly to acquire a French life, and indeed rejects the idea of French citizenship (75), her new life is very clearly modelled on French ones. It will not, however, be lived in France, but is destined for use back in Australia. It does not require prolonged residence in France: Holdforth manages to transform her life through a three-week trip to Paris staying with an Australian expatriate friend. Rather than a fantasy of belonging in France, this is then the story of the creation of a French-inspired self_-more sophisticated, more confident, more successful, perhaps happier.

\footnotetext{
${ }^{14}$ Language awareness in the corpus of Australian memoirs of relocation to France is the subject of a forthcoming paper. Meanwhile, Mary Besemeres notes that 'It is symptomatic of the global dominance of English that questions about language and identity are largely invisible in anglophone travel writing' (2008: 245).
} 
For Holdforth, gender is the critical issue, as the question prompting her trip to Paris demonstrates: 'At the age of thirty-five, as I start the rest of my life, am I not simply wondering this: How to be? Or more exactly, how to be as a woman?' (158, original italics). Dissatisfied with her Australian existence, she turns to the biographies of illustrious women who spent time in Paris for models: Colette, Nancy Mitford, and Edith Wharton among others, writers who 'had always had something to say to me about being a woman, about crafting a beautiful life' (6). Her predecessors are not necessarily French, but all made Paris their home. Holdforth, then, is seeking a Parisian life, not a French life; she explicitly rejects the rural idyll (26, see also 76) in favour of the liveliness and wit of the capital.

Holdforth feels the need to follow literally in the footsteps of these women, visiting the parts of the city they occupied, seeking a connection to this community through a connection with place. Through her reading, she comes to see Paris as a space where one can 'craft[]' one’s life (6), 'free’ (12), 'reinvent' (12), 'define’ (13), 'recharge’ (21) and 'create' $(21,95)$ oneself as a woman, and this will be her mission too in the city, to transform her old life into a new one. Even more explicitly than the other three authors, Holdforth participates in the discourse of the autonomous self who plots the course of her life (159).

Like Archer, Holdforth promotes the idea of a life as a masterpiece, but her aesthetic is less visual-it concerns the shape of one’s life: ‘the women of Paris ... came to represent important things to me: the grand scale that an individual life can achieve; the beautiful arc that a finished life can describe; the radiant, limitless scope of female potentiality' (7). In the lives she studies, Holdforth seeks alternatives to the expressions of gender and gender relations available to her in Australia. She sees French femininity as understated elegance $(9,50)$ rather than glamour: It 'looks effortless, but of course it isn't. And it's damned hard to copy' (50). She schools herself in techniques for achieving it; a manicure is a lesson in French aesthetics: 'The effect is one of heightened reality: Everything looks natural, only much better, natural in a way that poor old nature could never hope to achieve. Somehow this seems to me very French' (133). Once again, Frenchness requires discipline and appears in terms of general selfimprovement rather than a specific cultural form: natural, only better. Such contrived naturalness again points to the performative nature of the French femininity she seeks. 
Holdforth identifies French femininity as a potential—and potent (69-70)—element of her new self. Beyond looks, she seeks to emulate the maturity (169) of French femininity which appears ‘complex and interesting' (51), rather than 'girly' (51) — the Australian mode that never suited her. Her reflections amount to a rejection of Australian gender norms where, in her view, women 'missed our chance to be the decorative sex' (140) and female politicians largely mirror their male counterparts (179). Holdforth celebrates the importance of conversation, wit and intelligence in male/female interaction in France, and finds there the antidote to her experiences in Australian social and political circles. She sees France as shaped by a history in which 'men and women mixed in all circumstances of life' (82) and women were considered fundamental to civilization (168), thus providing a model for revising the gender scripts available to her.

During her three weeks in Paris, Holdforth reinvents herself as a woman in the style of her historical models, undergoes nothing less than a revolution that will 'direct[] the future course of her existence' (221), lending grace and purpose (220) to her hitherto messy life. Although not clearly defined, the new self will be an improvement on her previous one. And for those who would follow her, there is once again a toolkit: this time a reading list of biographies and histories rather than an address book.

Holdforth’s Paris resembles what Mary Louise Pratt identifies as 'feminotopias’ in travel writing: 'episodes that present idealized worlds of female autonomy, empowerment, and pleasure' (2008: 161). It also echoes Betsy Wearing's reading of leisure spaces as Foucaldian heterotopias: spaces for women to 'reconstitute[e] the self and rewrite[e] the script of identity' (1998: 146). Yet for Holdforth, while Paris is characterized by pleasure, it is not a space for leisure but for applying oneself to the art of living. Of the four authors, only Holdforth sees Paris as liberating, but even in this case it gives the freedom, not to let go or become 'sloppy and self-indulgent' (29)_ 'Paris is not a relaxed city’ (50); even her 'lazy Australian mouth’ needs to be 'energise[d] ... to perform the acrobatics of French vowels and diphthongs' (2) — but to achieve, to transcend. Indeed it is the freedom to discipline oneself.

\section{Mapping Frenchness}

Each of the four authors discussed here explicitly realizes Judith Adler's conception of 
travel as 'performed art,' whereby travel becomes a medium for 'self-fashioning' and 'bestowing meaning on the self and the social ... realities' through which one passes (1989: 1368). Although the myth of Paris as glamour and romance is their starting place, these writers go beyond it to embrace Paris as a fantasyland of self-transformation, where Australian women can create a supposedly 'French' life, a cultural performance of a new improved self, a work of art. It is a particularly feminine project: there are no examples in the corpus of men seeking to be French or to conform to a French ideal of masculinity. ${ }^{15}$ The authors differ principally in the degree of self-awareness they show in pursuing it: Archer's wholesale embrace of French culture contrasts with McCulloch’s irony, Nielsen’s candour and Holdforth’s self-analysis.

This French life does not require native-like proficiency in the language, or years of residence, or a French social circle. It need involve only minimal interaction with French speakers, and does not depend on recognition of one's Frenchness by French natives. Rather, it is achieved through a combination of identification, technologies of the self, and middle class tastes, money and sense of autonomy and entitlement. The projection of oneself as (at least partially) French demands self-regulation, training body and mind to fit a certain myth of Frenchness absorbed prior to travel. It is not difficult to identify external pressures (in the form of media discourses for example) to conform to this image of glamour, refinement and consumption, and the neat fit between the selfdiscipline envisaged by the authors and the production of willing consumers participating in the global economy illustrates Foucault's concept of governmentality on a supra-national scale (1988: 19). These pressures are nonetheless fully internalized in the memoirs such that the author feels that she is taking control of her own destiny in embarking on the project of a French life.

The discourse of self-discipline, the voluntary acceptance of new constraints by the authors contrasts directly with the tales told by British travellers to the Mediterranean. For more than a century the 'Sunny South' has been a space of 'escape from the physical, mechanical and spiritual constraints of British modern life,' a site of 'moral, intellectual, and sexual liberation’ (Moyà-Antón 2011: np). But whereas other Anglophones may be seeking sunshine and abandon in France, for these twenty-first

\footnotetext{
${ }^{15}$ Bryce Corbett, for example, is scathing in his descriptions of French men: 'unlike my French counterparts I had neither appalling fashion sense nor acute halitosis’ (2007: 66).
} 
century Australian women, France is a site of self-regimentation rather than relaxation, and they are unlikely to be impressed by the amount of sunshine.

The project of Frenchness may be most visible among self-confessed Francophiles, but should not be seen as foreign to those of us in the discipline of French Studies who seek to refine our linguistic skills and cultural competence in our forays to France. In the memoirs studied, however, language and culture are perceived as only one way of attaining Frenchness and not the easiest. Attention to grooming, acting the part, reading literature, new lingerie, a favourite café: these are equally recommended paths to Frenchness. And real estate is a shortcut for those with the means. But the link to place, however tenuous, is essential: setting foot in Paris — even if only for a few weeksauthenticates the self that is forged in France.

Rather than being simply faux-French, the claiming of French identity by these writers highlights some intrinsic aspects of cultural mapping. For mapping too is a technology of identification and may even be a work of art (mappae mundi providing splendid examples). Like the memoirs, the highly technical craft of mapping is an active process in which a particular projection-literally a flattened out image that necessarily distorts what it purports to show-is selected according to the map’s purpose. Far from simply representing geographical certainty, maps are relational, a projection of 'there' from 'here,' often highlighting particular landmarks or trajectories.

'Mapping' thus seems a particularly appropriate metaphor for the cultural and personal project of these writers. Each of these four authors maps a Paris, a life to live, and even provides precise itineraries to follow: Archer's address book; Holdforth's historical pilgrimage; McCulloch’s daily route through the Left Bank; Nielsen’s apartmenthunting all provide landmarks for a French life. These then are Australian mappings that do not coincide with the cultural pathways of the native French but are superimposed on them. They represent a peculiarly Australian, feminine cultural purpose and construction of Frenchness but as such are ultimately perhaps only marginally more imaginative than any other 'imagined community.'

\section{Reference List}

Adler, J. 1989, ‘Travel as a Performed Art,' American Journal of Sociology, vol. 94, no. 6, 1366-91. 
Ambrose, M. 2005, How to Be French. New Holland Publishers, Frenchs Forest, NSW.

Archer, V. 2006, My French Life. Penguin Australia, Camberwell, Vic.

2009, French Essence: Ambience, Beauty and Style in Provence. Penguin Australia, Camberwell, Vic.

Besemeres, M. 2008, 'Australian “Immersion” Narratives: Memoirs of Contemporary Language Travel,' in Transnational Ties: Australian Lives in the World, (eds) D. Deacon, P. Russell \& A.Woollacott. ANU E Press, Canberra, 245-57.

Bourdieu, P. 1979. La Distinction: Critique sociale du jugement. Editions de Minuit, Paris.

Butler, J. 1990, Gender Trouble: Feminism and the Subversion of Identity. Routledge, New York.

Corbett, B. 2007, A Town Like Paris: Falling in Love in the City of Light. Hachette Australia, Sydney, NSW.

Coulson, C. 2008, Paris Tango. Penguin Australia, Camberwell, Vic.

Foucault, M. 1988, 'Technologies of the Self,' in Technologies of the Self: A Seminar with Michel Foucault, (eds) L.H. Martin, H. Gutman \& Pa.H. Hutton. University of Massachusetts Press, Amherst, 16-49.

Genoni, P. 2007, 'Unbecoming Australians: Crisis and Community in the Australian Villa/ge Book,' Australian Literary Studies, vol. 23, no. 2, 213-29.

Greenblatt, S.J. 1991, Marvelous Possessions: The Wonder of the New World. University of Chicago Press, Chicago.

Hanna, B.E. \& =de Nooy, J. 2006, 'The Seduction of Sarah: Travelers’ Tales and Intercultural Learning,' Portal: Journal of Multidisciplinary International Studies, vol. 3, no. 2. Online, available: http://epress.lib.uts.edu.au/ojs/index.php/portal/article/view/117/311 [Accessed 1 July 2010].

Holdforth, L. 2004, True Pleasures: A Memoir of Women in Paris. Vintage, Milsons Point, NSW.

Holland, P. \& Huggan, G. 1998, Tourists with Typewriters: Critical Reflections on Contemporary Travel Writing. University of Michigan Press, Ann Arbor.

Kershaw, A. 1993, Village to Village: Misadventures in France. Angus \& Robertson, Pymble, NSW.

Lancaster, R. 2008, Je suis australienne: Remarkable Women in France, 1880-1945. University of Western Australia Press, Crawley, WA.

Mayle, P. 1990, A Year in Provence. Knopf, New York.

McCulloch, J. 2008, La Vie Parisienne: Looking for Love—and the Perfect Lingerie. Pier 9, Millers Point, NSW.

Moyà-Antón, E. 2011, 'British Literary Diaspora in the Mediterranean: The (Re)Creation of the "Sunny South,”' Kaleidoscope, vol. 5, no. 1. Online, available: http://www.dur.ac.uk/kaleidoscope/issues/v5i1/ [Accessed 1 July 2012].

Nielsen, E. 2007, Buying a Piece of Paris: Finding a Key to the City of Love. Scribe, Carlton North, Vic.

Pesman, R. 1996, Duty Free: Australian Women Abroad. Oxford University Press, South Melbourne, Vic.

Pratt, M.L. 2008, Imperial Eyes: Travel Writing and Transculturation. 2nd ed., Routledge, London \& New York.

Rojek, C. \& Urry, J. (eds) 1997, Touring Cultures: Transformations of Travel and Theory. Routledge, London \& New York.

Tisdale, S. 1995, 'Never Let the Locals See Your Map; Why Most Travel Writers Should Stay Home,' Harper's Magazine, 1 September: 66-74.

Turnbull, S. 2002, Almost French: A New Life in Paris. Bantam Australia, Milsons Point, NSW.

Wearing, B. 1998, Leisure and Feminist Theory. Sage, Thousand Oaks, CA.

White, R. 1987, 'The Soldier as Tourist: The Australian Experience of the Great War,' War \& Society, vol. 5, no. 1, 63-77.

Whitlock, G. 2000, The Intimate Empire: Reading Women’s Autobiography. Cassell, London \& New York. 